\title{
Science reorganized? : Post-modern visions of research and the curse of success
}

Citation for published version (APA):

David, P. A. (1996). Science reorganized? : Post-modern visions of research and the curse of success. MERIT, Maastricht Economic Research Institute on Innovation and Technology. MERIT Research Memoranda No. 002 https://doi.org/10.26481/umamer.1996002

Document status and date:

Published: 01/01/1996

DOI:

10.26481/umamer.1996002

Document Version:

Publisher's PDF, also known as Version of record

\section{Please check the document version of this publication:}

- A submitted manuscript is the version of the article upon submission and before peer-review. There can be important differences between the submitted version and the official published version of record.

People interested in the research are advised to contact the author for the final version of the publication, or visit the DOI to the publisher's website.

- The final author version and the galley proof are versions of the publication after peer review.

- The final published version features the final layout of the paper including the volume, issue and page numbers.

Link to publication

\footnotetext{
General rights rights.

- You may freely distribute the URL identifying the publication in the public portal. please follow below link for the End User Agreement:

www.umlib.nl/taverne-license

Take down policy

If you believe that this document breaches copyright please contact us at:

repository@maastrichtuniversity.nl

providing details and we will investigate your claim.
}

Copyright and moral rights for the publications made accessible in the public portal are retained by the authors and/or other copyright owners and it is a condition of accessing publications that users recognise and abide by the legal requirements associated with these

- Users may download and print one copy of any publication from the public portal for the purpose of private study or research.

- You may not further distribute the material or use it for any profit-making activity or commercial gain

If the publication is distributed under the terms of Article $25 \mathrm{fa}$ of the Dutch Copyright Act, indicated by the "Taverne" license above, 


\author{
Science Reorganized? \\ Post-Modern Visions of Research and the Curse of Success* \\ by \\ Paul A. David \\ All Souls College, Oxford \& Stanford University
}

December 1995

*This is a much expanded version of the text delivered by the author in an After Dinner Speech to the International Symposium on Measuring the Impact of R\&D, held in Ottawa, 13-15 September 1995. It has benefitted from Harvey Brooks' insights into the current science policy debate in the U.S., communicated in private correspondence and only imperfectly acknowledged in the text and footnotes. The comments and suggestions for improvements provided by W. Edward Steinmueller also are gratefully acknowledged. The author alone must be held culpable for the substantive views expressed, as well for retelling a favorite joke in the prologue.

Author's Address: P. A. David, All Souls College, Oxford OX1 4AL, U.K. Telephone: $+44+(0) 1865+279313 ; \quad$ Fax: $+44+(0) 1865+279299$

Email Address: <pdavid@vax.ox.ac.uk>; or <pad@leland.stanford.edu> 


\section{Obligatory Prologue}

Good Evening, Minister [Jon] Gerrard, Peter Morand, Ladies and Gentlemen of the Symposium. It is an honor for me to appear in this role before so distinguished an international assembly. In doing so I am conscious of the weighty responsibilities that are laid upon the after-dinner speaker. The first of these duties is to tell a joke, and I shall not shrink from it. You should notice that it is a somewhat self-referential story:

An early Christian was flung into a late Roman arena for the entertainment of the spectators, and a very large lion immediately approached him. Leaning over, the Christian took hold of the creature's mane and said something that was quite inaudible to the watching crowd. The lion slunk off to the other end of the arena and sat down.

The crowd was outraged and the Emperor, who was presiding over this spectacle, immediately signalled for another, hungrier lion to be released. Again the lion came bounding across the arena and, once again, the Christian leaned over, took hold of the animal and, to the renewed dismay and disgust of the spectators, the second beast turned away. The Emperor then ordered his guards to fetch the Christian, who soon was brought up before him. "Tell me, and I might spare your life", demanded the Emperor, "what is the secret thing you do to repel these wild beasts?" "Oh", said the Christian, "it's really quite simple: I remind them that after dinner there will be speeches."

You laugh, and yet, it would seem that you are not as smart as the lions in my story. You all have read what was to come next on the program, and perhaps you thought it was not going to be too hard, and you could go ahead happily and consume the sumptuous dinner without suffering serious consequences.... On the other hand, perhaps you believe you're a lot smarter than the lions, because you have learned that a really good meal will soon induce drowsiness and that sleep will allow you to escape the scheduled consequences.

But, if you've been thinking that way, I am sorry to have to say that you've made a terrible miscalculation. My story is not just a Christian-meets-Lion joke. It is about a Christian, some lions, and an Economist. I am the economist, and, you should have taken into account that modern economists all agree -- itself a remarkable thing! -- that social efficiency in resource allocation requires that people who ask to receive benefits should expect to bear the costs of their provision. So, you have had the benefits of the splendid meal provided by NSERC and our hosts this evening, and now you must bear some of the entailed non-pecuniary costs: I mean to tax away your enjoyment of a blissfully somnolent state of undistracted digestive activity. 


\section{Planning Science and Planning for Science -- An Evolving Policy Debate}

Measuring the Impact of $R \& D$ is the announced theme of this Symposium. By now, however, I think it has become plain to all of us that there is a deeper agenda, a subtext - if you will -- to both the printed program and the discussions in which we have been engaged. The Design and Impact of National R\&D Policies is the real subject matter that has been preoccupying most of us, and it is that broader theme that I intend to address on this occasion. So, you can relax a bit, for, I am not going to try to unfold the latest wrinkles in bibliometrics, or econometric approaches to estimating the social rate of return on $R \& D$ expenditures. Nevertheless, I do want through these remarks to encourage you to attend to the connections between those two themes, and the consequent importance of what might seem to be the technical and methodological questions that were the scheduled subjects of discussion in today's sessions -- concerning evaluation procedures, assessment approaches, and the development of corresponding $R \& D$ indicators.

In the present conditions of fiscal stringency that grip the attention of public policymakers in so many of the nations from which we are here assembled, debates about the appropriate scale and direction of publicly funded scientific research, and the bearing of the latter upon technological progress and industrial productivity growth, have taken on a heightened sense of urgency. The re-evaluation and rethinking that currently is underway concerning the purposes and conduct of the collective enterprise of public sector science, and the issues arising from it that framed our discussions on the Symposium's opening day, could be portrayed as a potential watershed from which will flow the course of national science and technology policies the influence of which will extend well into the twenty-first century.

Watersheds and critical points, however, are recurring phenomena in the evolution of social, political and economic institutions. Instead of seeing as unprecedented the widespread calls for thorough re-examination of the rationale and organization of programs supporting basic and applied science, and instead of debating whether those developments are ominous or overdue, we might more usefully view them broadly as the latest stage of a debate that was initiated in Britain more than a half-century ago. 
Back in the 1930s the protagonists were the sociologist of science Michael Polanyi, and J .D. Bernal, a distinguished chemist, historian of science and technology, and a Marxist critic of the science establishment. ${ }^{1}$ Bernal felt that there was tremendous misdirection of talent and wastage of resources in the autonomous way that British science was being conducted. In his view, ${ }^{2}$ because the growth of the country's science establishment

"...proceeded in a uncoordinated and haphazard manner, the result at the present day is a structure of appalling inefficiency both as to its internal organization and as to the means of application to the problems of production or welfare. If science is to be of full use to society it must first put its own house in order."

This, however, would not be enough; at the end of the day, Science was too important, too powerful a source for good, to be left to the scientists. Bernal believed that the potential benefits of science for humanity, and the capacity of science to alleviate misery and improve social conditions in the context of the 1930s' British society, were enormous and therefore warranted the allocation of a greatly expanded share of the national product to $R \& D$. Such a program would only realize its potential through "a publicly discussed and debated flexible plan involving government and other representative elements of society". ${ }^{3}$

Michael Polanyi did not object to the contention that the commitment of national resources for $R \& D$ needed to be substantially increased. But he balked at following Bernal's call for national planning of science in the style supposedly being attempted in the Soviet Union, and he sought to counter the argument that Science needed to be put to work under directions provided by social elements other than the scientists who would be immediately involved. Polanyi stressed the need for autonomy and self-governance as

\footnotetext{
${ }^{1}$ The debate was carried on during the 1930s largely in the pages of the journal Minerva, but the main protagonists subsequently set out their respective positions in book form: Michael Polanyi, The Logic of Liberty, London: Routledge \& Kegan Paul, 1951; J. D. Bernal, The Social Function of Science, London: Routledge \& Kegan Paul, 1939. A recent reconsideration of the Polanyi-Bernal debate and its sequelae is provided by Christopher Freeman, The Economics of Hope: Essays on Technical Change, Economic Growth and the Environment, London: Pinter Publishers, 1993, Ch.1.

${ }^{2}$ Bernal, Social Function of Science (1939), p.xiii.

${ }^{3}$ The phrase quoted is from Freeman, Economics of Hope (1993), p.21.
} 
conditions necessary for the scientific community to contribute most effectively to social goals over the very long run. This did not imply that society should wait patiently for the application of scientific advances to its social problems. Rather, it meant that at any moment in time, the quality of the science available for such applications would be greater, and the stock of knowledge would be larger and more reliable, where the scientific research community had not been externally directed.

Although this British debate was suspended in the emergency of the Second World War years, it soon was renewed in the US at the close of that conflict, partly in the light of the role that the mobilization of science had played in the war effort and the success of the alliance. ${ }^{4}$ On that occasion Vannevar Bush, then Director of the U.S. Office of Scientific Research and Development, emerged as the champion of Polanyi's views; while Senator Kilgore, a Roosevelt Democrat but no Marxist, took up what was essentially the Bernal view.

Kilgore was enthusiastic in his support for Science and Technology, for research as the way to achieve societal goals and economic growth, full employment, health and welfare, but he wanted this process linked to political institutions and priorities. He wanted political and social accountability, and more attention to the geographical distribution of research and research findings. Kilgore wanted efficiency in the production of knowledge that was of manifest social utility to be made the sole criterion for the selection of scientists and institutions to receive public support -- just as in Great Britain today the adherents to this science policy approach have sought to forge a national "strategy for science, engineering and technology" the touchstone of which is to be "wealth creation". Vannevar Bush, as is well-known, made the universities the centerpiece of his program recommendations for post-war science in the US, and he did so explicitly because of their

\footnotetext{
${ }^{4}$ See, Harvey Brooks, "Evolution of the U.S. Science Policy Debate--From the Endless Frontier to the Endless Resource," December 13, 1994 revision of a paper for the Brookings Institution/American Enterprise Institute Conference on Science Policy, held in Washington, D.C., on 3rd October 1994.

${ }^{5}$ See Realising Our Potential: A Strategy for Science, Engineering and Technology (Cm 2250), London: HMSO, 26 May 1993. The implications for the U.K. "science base" of the policy direction enunciated in this Government White Paper (the so-called Waldegrave Report) are discussed in House of Lords, Select Committee on Science and Technology, Priorities for the Science Base, ( Session 1993-94:2nd Report, HL Paper 12-I), London: HMSO, 15 December, 1993.
} 
independence, autonomy, and comparative insulation from commercial pressures. In the famous Bush Report (1945), it was taken to be virtually self-evident that: ${ }^{6}$

"Industry is generally inhibited by pre-conceived goals, by its own clearly defined standards, by the constant pressure of commercial necessity. Satisfactory progress in basic science seldom occurs under conditions prevailing in the normal industrial laboratory."

This was not a debate that was closed by the adoption of Bush's recommendations. The controversy over the social accountability of the National Science Foundation, for example, delayed its establishment for five years in Congress. In essence, this same debate recurred strongly in the 1970s, when once again there were powerful pressures to redirect the programs of science towards the solution of American society's problems, and away from the kinds of blue-sky research that military patriots in university defense-related labs and non-defense scientists were ready to support.

Overtones of this historic debate are readily discernable in the rhetoric of contemporary discussions of the re-evaluation of public funding strategies for science and technology and proposals for the reorganization of national $R \& D$ activities. A sub-theme of this social control versus autonomy rhetoric is a tension between open science, represented institutionally by the idea of the academy, and appropriable science, represented by influential segments of industry and politicians who embrace what sometimes becomes a techno-mercantilism strategy for national success in an era of global economic competition.

Of course, in the intervening decades the terms of debate have altered, inasmuch as the proposals originally advanced by Bernal in regard to the scale and intention of governmental activity in the field of science became the realities in Britain and the other industrialized countries of the post-WWII world. In 1939, when the proportion of GNP spent on $R \& D$ was one-tenth of one percent, Bernal called for a ten-fold increase that to many contemporaries seemed fantastic, but which by the mid-1960s already had been

\footnotetext{
${ }^{6}$ Vannevar Bush, et al.,Science: The Endless Frontier (A Report to the President on a Program for Postwar Scientific Research, 1945), Washington, D.C.:National Science Foundation, Reprint Edition, 1960, p. 19. For further discussion of this aspect of the Bush Report, see P. A. David, D. C. Mowery and W. E.Steinmueller, "University-Industry Research Collaborations: Managing Missions in Conflict," forthcoming in A Productive Tension: University-Industry Research Collaborations in the Era of Knowledge-Based Economic Development, eds. P. A. David and W. E. Steinmueller, Stanford, CA: Stanford University Press, 1996.
} 
achieved and was being judged inadequate to meet the nation's needs. Contemporaneously, economic analysts had articulated a new set of arguments that have become the accepted rationale for a greatly expanded volume of public funding of civilian $R \& D$. This holds that the information-products of research share the principal attributes of "public goods", a category of commodities for which decentralized resource allocation through markets can be shown to perform badly. ${ }^{7}$ Empirical evidence of the persistence of a positive gap between the private and social rates of return on investments in $R \& D$ was adduced in support of the theoretical conclusion that private commercial incentives alone are inadequate to elicit the socially optimal level of investment in research. ${ }^{8}$

On the other hand, public planning of any sort of economic activity nowadays is greatly out of favor, and it is especially hard to find any serious proponents for the brand of centralised, comprehensive social planning of science -- as distinguished from the planning of specific government-sponsored projects -- that Bernal had advocated. Most of the high-level disagreements about the future course of public science policy are now focused upon the balance between commercial and other social objectives, and consequently about the choice among alternative organizational modes that have differing implications for the nature and thrust of the incentives affecting the financing and conduct of $R \& D$. In practical science policy-making, the real issues are not those involved in the debate as to whether social needs rather than the internal logic of autonomous scientific disciplines should be as the drivers of research. No scientific disciplines can be wholly autonomous, and most science and technology is driven inevitably by social needs and guided by economically and socially determined conditions, especially when the scientific enterprise

${ }^{7}$ These attributes consist in the difficulties that discoverers and inventors would have in excluding others from the economically beneficial use of their additions to the stock of scientific and engineering knowledge, and the infinite expansibility of information as a commodity, which allows many to utilize it concurrently and sequentially without exhausting its substance. On the contributions of R.R. Nelson (1959) and K.J. Arrow (1962) to the development of this rationale, see P.A. David, "Knowledge, Property and the System Dynamics of Technological Change," in 1992 Proceedings of the World Bank Annual Conference on Development Economics, L.Summers and S. Shah, eds. (Supplement to World Bank Review), Washington, DC: World Bank Press, 1993.

${ }^{8}$ For further discussion, see, e.g., P.A. David, D.C. Mowery and W.E. Steinmueller, "Analyzing the Economic Payoffs from Basic Research," Economics of Innovation and New Technology, 2(1):pp.73-90. 
has grown to its present proportions. As the sociologist of science, Joseph Ben-David cogently remarked almost a decade ago:

"No good will result from adhering to the belief that the alternatives of science policy are central planning by government and laissez-faire. The questions are how to distinguish between the role of the government as a customer of specific scientific services and as a general patron of science and how to reconcile the role of government as the preponderant source of financial support with the existence of autonomous and enterprising scientific institutions. ${ }^{\prime \prime}$

But, as we notice, arrival at the "end of ideology" in this arena has not brought any lessening in the intensity of the passions and the interests engaged in debates over science policy. And it is the latter observation that brings me to the point telegraphed by the second phrase in the sub-title I chose for this talk: among the rewards of the success of modern science, one must count the "curse" of optimistic public expectations about the potentialities of research. It is the increasingly universal perception of scientific and engineering knowledge as an instrumentally -- the means of achieving a myriad ot private and social goals -- that continues to stir competition and conflict over practical details touching direction of research in pursuit of such knowledge, and the control of the uses to which the resulting discoveries and inventions may be put. Thus, the main issues of practical science policy today, have come down to questions of balance and degree, involving the terms of fundable programs, the control of research agendas, and the disposition of research results. I see these as vital issues not only in the detailed conduct of research, as the ground level, so to speak, but also for the macro-level performance of the entire science and technology insfrastructures of modern economies.

\section{From Ideology to Practical Issues in Science Policy}

There are three key, archetypal issues to which practical decision-makers responsible for allocating $R \& D$ resources must attend. ${ }^{10}$ The first of them can be posed as the question of what portion of public funding for Science and Technology should go to

${ }^{9}$ J. Ben-David, Scientific Growth: Essays on the Social Organization and Ethos of Science (Edited and with an Introduction by Gad Freudenthal), Berkeley, CA: University of California Press, 1991, Ch.12 ("The Central Planning of Science", first published in Minerva, 1977), p. 281.

${ }^{10}$ In identifying the first two issues I can do no better than to follow the recent formulation by Harvey Brooks, "Evolution of the U.S. Science Policy Debate" (1994): pp.32-33. 
research that is driven by the internal logic of the subject, that is, the development of conceptual schemes for their own sake. This is not a question encountered only in the public sphere; some large, $R \& D$-intensive business corporations also have sufficient resources to make it pertitent in their strategic planning. Research, however, is an uncertain proposition and such planning is insufficient to dispose of the underlying issue completely. Since many important fundamental science advances have derived from problems that were first encountered in practical contexts, a second practical choice point arises when one asks how far beyond the immediate need for a solution to the problem at hand one should encourage researchers to go in exploring the more general conceptual problems they have opened up, often thereby creating new demands for curiosity-driven research that otherwise would not have been discovered and could not be planned ex ante. One micro-level form in which this second, practical matter presents itself is how tightly specified as to budget, and how closely managed "from the top down" R\&D programs should be -- because that will determine the extent of the actual margins of discretionary control over resources that research units and individual investigators are able to preserve to pursue unexpected opportunities.

The third choice point involves the question of what is to be done with the findings. Because the opening of a new demand for investigation by seizing on the accidents of research often entails the mobilization of concepts, research talents and techniques imported into the emerging area from fields whose relevance was not immediately perceived (think of laser science and microsurgery, of molecular protein chemistry in relation to plant genetics, of computer science in relationship to gene sequencing), a further range of questions arise. How widely and how quickly are the findings that point to the existence of a new science to be disclosed? How fully are they to be disclosed, and to whom? How is the field to be best explored, by complete disclosures that will throw it open to all comers on an equal footing, or by policies of information management designed to keep direction and control in the hands of the original discoverers? As Stephen Hilgartner has remarked in his recent study of data access policies in human genome research: ${ }^{11}$

\footnotetext{
${ }^{11}$ Stephen Hilgartner, "Data Access Policy in Genome Research," Working Paper, Department of Science \& Technology Studies, Cornell University, Ithaca, 1995; p.5.
} 
"These matters are not trivial administrative details, but are the very essence of the policies and practices that constitute greater or lesser freedom of access. In addition, a broad philosophy [such as has been adopted by the Human Genome Initiative] leaves open the question of precisely how policies promoting free access should be structured and enforced. That these issues have at time provoked disagreement is not surprising, in light of competition for funding, priority, and intellectual property rights."

The terms of reference for resolving these practical issues generally are set by the operating styles, the organizational norms and goals, and the institutionalized codes of behavior of the research units in questions, and these latter, in turn, are powerfully shaped by the character of the reward systems and the prevailing incentives offered by the research units and the larger institutional contexts within which they operate. In other words, I am reminding you of what you know from your professional and personal experiences: the goals, identity and associated behavioral expectations of the organization matter to the way it takes up research questions, the way it conducts the research, and what it does with the results. Is the research unit a divisional polymer chemistry laboratory of a large multinational corporation, or a research site in a national defense lab? Is it a high energy particle research facility managed by the applied physics department of an elite research university, an AI group in a not-for-profit, or an interdisciplinary team temporarily occupying a university-industry science and engineering center? The norms, values and operating modes that carry those labels are not stable over time. They are subject to change. But, within the practical decision-makers' frame of reference, they drift slowly unless measures are taken from outside, by other forces impinging on the organization, to transform its character and, in consequence, alter the research it does and the nature of the impact that $R \& D$ expenditures channelled through that organization can be expected to make.

The significance of what I have just said for the interpretation of indicators and measures of $R \& D$ impact is not hard to see. $R \& D$ inputs we can measure quite readily, but the aggregation of those inputs up to the programatic, disciplinary, regional and national levels, masks information about the contexts of $R \& D$ efforts. Predictions of likely outcomes of impacts, consequently, are more prone to go awry if we do not understand the mix of contexts within which the research is being conducted. If you alter the actual operating modes of research organizations without tracking the transformed relationships between the label they carry and what has happened to those modes, even preserving the 
categorical labels on your account of where the research money is being spent (in a government lab, a university-faculty lab, an industrial lab) will not help very much when the changes that are impinging on those organizations destroy much of the value of the historical record as a basis for decisions about resource allocation in the present. Major shifts in organizational mix, and the cumulative drift of organizational norms, if they are not monitored, will leave us very much in the dark about what will be the consequences of this or that disposition of research resources.

A further, and quite important implication of this is that there is a need to evaluate how $R \& D$ policies that involve institutional innovation and reorganization will affect the mix of operating modes governing research performance. Let me give you one example to illustrate the importance of this point, based upon the findings of a recent survey of US university-industry research centers. The survey was conducted by Wesley Cohen, Richard Florida and Richard Goe, of Carnegie Mellon University, under the sponsorship of the Ford Foundation. ${ }^{12}$ Although virtually unnoticed at the time, university-industry research centers doubled in number and research volume during the 1980s, until by 1990 there were more than a thousand such units in the US, spending approximately 2.5 billion dollars on $R \& D$ and another 1.6 billion on research-related activities, including education and training.

One might think that this development was tantamount to a major, active industrial research policy, implemented with Federal and state funding under the aegis of the Reagan administration. But, as we know, that administration maintained that it steadfastly eschewed all such policies. Since so little attention has been given to this particular institutional innovation, I want to urge you to obtain and read the whole of the report to which I have referred, especially as the data it presents are based on a very good response rate of approximately $48 \%$-- so that there were more than 500 university-industry research centers (UIRCs) reporting, and the analysis has been carried through with great care and balance.

The single aspect of the work of Cohen et al. on which I want to focus here is one in which I had a small role. During the design stage of the Carnegie-Mellon survey, I was

\footnotetext{
${ }^{12}$ Wesley Cohen, Richard Florida and W. Richard Goe, "University-Industry Research Centers in the United States," Center for Economic Development, School of Public Policy Management, Carnegie Mellon University, Pittsburgh, PA. July 1994.
} 
able (without too much difficulty) to persuade the investigators to enquire into the operating modes of the UIRCs with respect to the third of my three key issues: organizational rules affecting the control of research findings. With regard to their fiscal management and administrative operating procedures, the UIRCs look completely like university organizations: $91 \%$ of them reported that industry had little or no influence over their fiscal management, $88 \%$ said the same with regard to administrative operations. But with regard to controls over information, the picture is quite different from the norms that usually are taken to apply to university-based R\&D activities: participating companies were allowed to restrict the flow of information both inside and outside the university research centers.

How extensively were such restrictive practices permitted? Approximately $57 \%$ of the UIRCs in the sample have some information control provisions. In 53\% of the centers, communication of information about research projects to non-participating companies was not permitted. That is quite understandable and, perhaps, only to be expected -- since both the participating firms and the centers administration share an interest in discouraging "free-riding". But, here are some figures that I did not fully anticipate, and which you too may find surprising. In $40 \%$ of the centers, information-flows to participating companies also were restricted if they were not involved in the particular project. So much for measures to stem to direct contacts with potential or actual industrial rivals; what about indirect leakage via the academic research community? Measures presumeably intended to curtail this were in place in $29 \%$ of the responding UIRCs, who reported restricting communications with university faculty members at large; in 21\%, communications with faculty of the center's own university was restricted; and, in 13\%, information-flows to faculty working within the center itself were subject to restrictions.

One more observation must be made on this point. We all are familiar enough with the fact that in university-industry collaborations, university rules have permitted delays in publication to permit the filing of patent applications in the US. Since the 1980 Bayh-Dole Act, the universities have been active participants in this, filing patents themselves. In the UIRCs studied by Cohen, Florida and Goe, approximately 53\% permitted such delays. It is not clear from their survey results whether the duration of these delays has been increasing, or whether the delays imposed at UIRCs tended to exceed those allowed in other university research areas. What is quite striking, however, is the finding that at over 
one-third of the centers not only could publications be delayed, but participating firms had the right to completely delete information from publications. This was the case in $54 \%$ of the centers when the mission was regarded by the company as very important to improving its product or process. Yet, it was also permitted in $20 \%$ of the centers where the mission was regarded as "not important to the sponsoring company"; in other words, in one-fifth of these university-industry centers the suppression of results had ceased to be a special discretionary matter and had become a matter of normal operating procedures!

Now, when I have facts such as these in mind, I find myself growing increasingly uneasy when listening to glowing reports -- such as the one presented to us yesterday with characteristic verve and enthusiasm by my good friend Professor Henry Etzkowitz -- about how entrepreneurial universities in the U.S. have "solved the conflict between the spheres of academia and industry", and how this has been resolved in favor of entrepreneurial professors who have "learned how to keep back details of their research" that they know to be potentially commercializable. Is it just terribly old-fashioned on my part to wonder whether we should we be quite so sanguine about modes of organizing $R \& D$ that are emerging at the interface between the worlds of the academy and the corporation?

\section{Post-Modern Visions of Science -- What Are They Telling Us?}

It is just such worries that have brought me to want to talk briefly about the other thing that my title referred to, namely, "Post-Modern Visions of Science". Although some may object to my interjecting an allusion to postmodernism into this discussion, I suggest it is a convenient and not too misleading label for the bundle of ideas and policy messages spun from some"advanced" thinking about the nature of scientific and engineering research. During the past two decades these have been telling us that organizational norms and institutions really never mattered to the progress of science in the West, don't matter now, and won't matter in the future; that the essence of science as a system of knowledge production consists in sets of beliefs, practises, proceedures and artifacts that collectively constitute their own environments, and whose functioning is pretty much independent of, and, therefore, readily separable from the particular institutional and organizational moulds into which they happen to have been pressed in the past. 
Two particularly clear strands of thought are joined in this view. The first is found in the works of the sociologists of scientific knowledge who have been focusing on the content of what is accepted as "science", and not on the specific social and institutional context(s) of science, as, for example, Robert $K$. Merton and the whole generation of sociologists of science working under his inspiration had done in the 1960s and 1970s. ${ }^{13}$ The second derives from observations of recent changes that have been taking place in the mode of organization of research, associated with the increased prevalence of missionoriented multi-disciplinary $R \& D$. Before going further to comment on. their larger import, I shall need to describe each of these strands a bit more fully, taking them in turn.

The sociologists of scientific knowledge who I have in mind ${ }^{14}$ are "postmodern" in philosophical outlook, being disposed to reject the notion of a sharp dicotomy between an objective nonhuman world of nature, and human culture. To be "modern" for Bruno Latour is to subscribe also to the illusion of that society is organized into distinctive sub-structures and decomposable into subsystems, whereas the "reality" is a set of network relationships comprising human and nonhuman elements, all of which should be accorded approximately equivalent status. ${ }^{15}$ In making the legitimate point that there was some important connection between social groupings (communities and networks) and the cognitive subjects of their concern, the language, and hence the content of their relationships -- i.e., that language and social structures were dual, because all relationships could be viewed as "discourse" -- the new sociology of scientific knowledge

${ }^{13}$ See R.K. Merton,, The Sociology of science:Theoretical and Empirical Investigations. Edited by N.W. Storer (Chicago: University of Chicago Press) 1973.

${ }^{14}$ For my present purposes it is permissible to dispense with many nice distinctions that could and in other contexts should be drawn between the followers of Barry Barnes, David Bloor and the Edinburgh "strong programme" for the sociology of scientific knowledge, the "social constructionists", and the sociological-anthropological network around Bruno Latour and Michel Callon at the Ecole des Mines in Paris. See, inter alia, B. Barnes, Interests and the Growth of Knowledge, (London: Routledge \& Kegan Paul), 1977; D. Bloor, Knowledge and Social Imagery (London: Routledge \& Kegan Paul), 1976; M. Callon, ed., La Science et ses réseaux: Gènese et circulation des faits scientifiques, Anthropologie des sciences et des techniques ( Paris: La Découverte), 1989; M. Callon, "Four models for the dynamics of science," in S. Jasanoff, G.E. Markle, J.C. Petersen and T. Pinch (eds), Handbook of Science and Technology Studies (London: Sage Publications), 1995; B. Latour and S. Woolgar (1979), Laboratory life (Beverly Hills: Sage Publications); B. Latour, We Have Never Been Modern, Translated by Catherine Porter (Cambridge, MA: Harvard University Press) 1993.

${ }^{15}$ See Latour, We Have Never Been Modern (1993): pp. 10-12. 
has de-emphasized the role of specific institutional contexts and norms in shaping science as a distinctive social activity.

In the view of Michel Callon, for example, it is wrong to think that science produces "public goods" in the form of knowledge, because science is not and never has been associated in an essential way with any set of institutions that had rules governing the disclosure of knowledge. Here is what he has said recently, in a public lecture questioning whether science is a public good: ${ }^{16}$

"without institutions that have been created and reinforced over the centuries, without intense energy invested by scientists and the state to make scientific knowledge public, this latter would never have ceased being what it has always been: a potentially privatizable good, not different in that from other goods."

One thereby is invited to suppose that in the absense of those imposed institutions the same stock of knowledge automatically would have come into existence in the form of intellectual property. Although having thus dismissed the "appropriability problems"rationale of Arrow (1962) and Nelson(1959), Callon does goes on in the same article to propose a new and different line of justification for public subsidization of science . Others of the "relativist" persuasion, however, have been more inclined to follow Paul Feyerabend's critique, ${ }^{17}$ in seeking to deprive the scientific establishment, qua establishment, of any basis for its claims to patronage and autonomy from society at large.

A common contention underlying all this is that the adherence to particular organizational forms, and the prescription of certain institutionalized roles, are is not what constitutes modern science or gives it legitimacy. With this many, myself included, would agree. But, it needs to be said also that this contention seems quite incorrect when it is taken to mean that the continuing efficacious application of the scientific method does not require maintaining an ethos of "openess" and "cooperation" among researchers, supported by the presupposition that the "reliability" of scientific statements is a collective product requiring independent verification, and consequently conformity with some behavorial norms regarding the disclosure of their findings.

${ }^{16}$ M. Callon, "Is Science a Public Good?" The Fifth Mullins Lecture, delivered at Virgina Polytechnique Institute, 23 March 1993, Science, Technology \& Human Values, 19(4), 1994: pp. 395-424.

${ }^{17}$ Against Method, London: New Left Books, 1975. 
The argument that for there to be reliable (scientific) knowledge products such collectivities need to constitute themselves as scientific disciplines -- sometimes referred to as"invisible colleges" -- is no longer one that commands automatic assent among sociologists of knowledge. Indeed, in some circles it now is derided as hopelessly "modern", and in others it is disparaged as intellectually reactionary -- for seeming to interpose institutional obstacles to new, trans-disciplinary modes of inquiry. That is one of the direct challenges recently issuing from a bold vision of the future, as discerned by some trend-spotting students of the international science and technology scene -- a vision that is "post-modern" in a sense different from that of the sociologists of scientific knowledge.

From this, the second of the dual strands of thought I have identified, "science" emerges as synonymous with "research" -- a universal methodolgy of inquiry and mindset that already can be seen to characterize the activities of all researchers of sorts, working under all manner of organizational arrangements, many of which have no correspondence to the institutional conditions or the cognitive structures of academic disciplines. Whereas for Max Weber and ensuing generations of sociologists of knowledge, science was something quintessentially rationalist and "modern" -- and associated only with some parts of late nineteenth century and early twentieth century society in the West, and with the ethos and norms particular to that sub-community -- the observational post-modern vision sees the techniques of problem-solving as having become generalized to the whole of society. On this forward-looking view, mission-oriented $R \& D$ is well on its way to displacing discipline-based scientific practice, and becoming a ubiquitous and institutionally de-contextualized activity.

This particular outlook is epitomized in the recent book, The New Production of Knowledge, by Michael Gibbons, Camille Limoges, Helga Nowotny, Simon Schwartzman, Peter Scott, and Martin Trow. These authors form a collectivity (who I will refer to hereafter as GLNSST) of a size and academic weight sufficient to require our taking serious notice of the intellectual position their work represents. ${ }^{18}$ Having "GLNSST the future", so to speak, they have reported a range of trends and tendencies in scientific and

${ }^{18}$ See M. Gibbons et al., The New Production of Knowledge: The Dynamics of Science and Research in Contemporary Societies, London: Sage Publications, 1994. 
scholarly activities, which, through their interactions and combined influences, appears to constitute a transformation in the mode of knowledge production. The new configuration, which GLNSST labels Mode 2, contrasts with the traditional knowledge production mode which goes on within the disciplinary, primarily cognitive contexts associated with academic science (Mode 1). Mode 2 knowledge is created in broader transdisciplinary and socioeconomic contexts. It is application-oriented in the sense that problem-solving is organized around and coterminous with the achievement of a particular application, not in the sense of solving problems encountered in an applications context. It is tran-disciplinary, and occurs primarily through local social networks. Details of problem solutions are not immediately made public knowledge by disclosure through the institutionalized media of pre-prints, working papers and so forth, but, instead, results are communicated only to those who have sponsored and participated in the inquiry. Diffusion occurs only through the movements of such people into different contexts of application. It is organizationally and locationally transient: research teams assemble, break up, and disperse or move on to other sites. They do not outlive the problem-solving tasks for which they were formed. It is distributed institutionally -- science projects of this sort can be carried on in many different settings, and Mode 2 knowledge production can thus be conducted concurrently at many sites: universities, institutes, research centers, industrial labs, all of which are daily becoming more closely linked by electronic communications media.

In first introducing Mode 2, GLNSST assert they have made no judgement "as to the value of these trends -- that is, whether they are good and to be encouraged, or bad and resisted...."19 This disclaimer, however, turns out to be somewhat disingenuous. The text immediately goes on to note that Mode 2 is what you find when you are looking at the frontiers of scientific research, and when you concentrate on the way that the scientific elite, the most productive people at any time, are working. And, in the ensuing pages (pp. 3-10) the attractions of Mode 2 are further delineated: to the individual researchers it provides "a stimulating work environment" that features "access to challenging intellectual problems" and "close collaboration with experts from a wide range of backgrounds"; furthermore, at the societal level Mode 2 offers flexibility, rapid response times, and social accountability.

\footnotetext{
${ }^{19}$ Gibbons et al., The New Production of Knowledge (1994): p.1.
} 
The more neutral clothing of the introductionary language having thus been discarded, the future organization of research envisaged by GLNSST soon reveals itself dressed in a promotional garb familiar to students of Hegelian and Marxian rhetoric: plainly, it is the Zeitgeist, the spirit of the age, and therefore something with which we should be striving to align ourselves. I quote again from their text :

"Mode 2 is a response to the needs of both science and society. It is irreversible. The problem is how to understand and manage it. (p.11)....There is no imperative for all institutions to adopt the norms and values of the new mode of knowledge production. Some firms and universities are already a long way along the path....However, the institutional goals to be achieved, the rules governing professional development and the social and technical determinants of competence will all need to be modified to the extent that the new mode becomes established.... (p.13); Mode 2 is creating new challenges for governments. National institutions need to be decentered -- to be made more permeable - and governments through their policies can promote change in this direction....It is perhaps ironic that it should fall to governments to punch holes in the very institutions that in an earlier day were established to maintain its science and technology capabilities. But, along with other apparently fixed notions, the purpose and function of these institutions needs to be rethought in the light of Mode 2."(p.15)

Now, punching holes in institutions and organizations seems to go rather beyond rethinking. What we have here is a quite radical policy stance, and in that respect not altogether alien to the spirit of Bernal in his day --, although, somehow, I doubt that GLNSST would welcome this association. It is a program premised on the certainty that a way has been found to unchain the scientific method, to release it from its outmoded formal institutional and organizational shackles and put it to work in the service of society. Indeed, in order for the nascent Mode 2 rapidly to realize its own potentialities, obstructing remants from the past must be cleared away. Numerous existing institutions - universities, public research organizations, discipline-based peer-review systems of grant funding, and still other which GLNSST tell us are in need of being "decentered" and "ventilated", represent merely a superstructure erected on the substructure of an old and obsolete mode of knowledge production.

When one puts together the two post-modern visions that I have described here, the result is a stereopticon image, a vivid "3-D" picture whose salient import is that we at last have at our disposal the universally potent and dependable methodologies of "science" and 
can make policies to deploy them for wealth creation or other purposes, in any way, and under any conditions that we find expedient. There are no attendant infrastructural constraints; you can have any kind of research organizations that you want, and the less constraining of how you exploit new knowledge, the better. This is where the curse of success enters once again: science-based technological innovation has paid off handsomely, and it appears that at the cutting edge, the new knowledge can be generated in any environment--commercial lab or university lab are on an equal footing in biotechnological breakthroughs and the development of new parallel processing architectures. It's "science" qua method, not the Republic of Science qua institutionalized mode of inquiry that produces reliable knowledge, and where it does it is not an essential part of the story. On this reading, the provenance of the transistor, and restriction-enzyme technology in academic and quasi-academic research organizations is not considered to tell us anything save that Stanford, the University of California, and Bell Labs just happened to be the "sites" at which the lightening struck on those occasions.

\section{Potential Institutional and Organizational Impacts on Measured Impacts of $R \& D$}

My first response to these visionaries is to shout a warning: "No! Stop! You've got it upside down -- the functions fulfilled by those institutions were essential, a part of the infrastructure, not the dispensable superstructure." In my way of looking at the matter, there has been and still is so vital a connection between the institutions and the organizational structures associated with "open science",on the one hand, and the wonderful scientific benefits that flowed from past expenditure in $R \& D$, on the other, that we should be very wary to supposing we can predict what will happen if our societies were to go on spending large amounts of money under a very different mode of organization for scientific research. ${ }^{20}$

It is my view that as a result of the intellectual evolution that I have been describing, the organizational and institutional side of the success of modern science has come to be dangerously under-appreciated. I see the Scientific Revolution as having had two faces, and as having left two legacies. One lay in the cognitive domain, the other in

${ }^{20}$ This position, very much in the tradition of Polanyi, has been elaborated using conceptual tools from modern economic analysis in Dasgupta and David, "Towards a New Economics of Science" (1994). 
the domain of social organization. In the latter, "open science" was an organizational innovation, a departure from the long antecedant tradition of the secret pursuit of Nature's secrets. As I have argued elsewhere, the public disclosure of new scientific discoveries and inventions was a solution to problems of legitimation and validation that had been created for the Renaissance system of patronage by the dual epistemological novelties that fused into the new natural philosophy -- sophisticated mathematics,on the one hand, and experimental demonstration, on the other. ${ }^{21}$

The opposing conviction, that science is an organum that will function with equal effectiveness in any social environment, under any organizational conditions, might seem to be justifiable in the light of the success of wartime scientific mobilizations. But that is an illusion conjured up by a misreading of the historical record. Vannevar Bush himself believed in 1945 that the wartime successes were won by a necessarily short-run strategy that entailed putting to work the stock of basic and applied scientific knowledge previously accumulated under other, quite different conditions. Similarly, today, it has been possible for R\&D teams in one country to put to use more effectively than others the store of scientific information that has been built up through a long process of international collaboration and cooperation. Opportunistic behavior may be very successful in this domain, given the ease of appropriating the benefits of codified information, so long as the practice does not become universalized. But another sting in the curse of success is that successful short-run strategies are those most likely to be widely imitated.

Along with many other economists of an historical bent (including at least one recent Nobel Laureat, Douglass North), I also insist that institutions mattered not only in the past, but continue to matter for the future. The immediate connection in which that simple truth seems well worth repeating before an audience such as this, which is professionally concerned with developing more informative indicators of the results of $R \& D$ performance, is that the institutional infrastructure and organizational norms of behavior will affect the measurable "impacts" of R\&D activities. Suppose one takes the black box approach to $R \& D$, which is what much of the economic analysis of the subject still does. We can measure the flows of resources going in, which is what is done by the

\footnotetext{
${ }^{21}$ See P. A. David, "Reputation and Agency in the Historical Emergence of the Institutions of 'Open Science'," MERIT Memorandum, University of Limburg, Maastricht, January 1994.
} 
Frascati Manual generation of statistical indicators, and we can think of the ultimate resultants in terms of a distribution of rates of return on the investment in performing the $R \& D$.

It is useful at this point to introduce the notion that there is a distribution of returns, and to get away from thinking only in terms of the rate of return. $R \& D$ is an uncertain process at the cognitive level, and there are further uncertainties in the conversion of whatever knowledge will have been produced into economic benefits (reduced costs of processes, or increased consumer surplus from cheaper and/or better goods). Notice, then, for future reference, that the average rates of return commonly referred to in discussion of payoffs from such activities rarely are adequate to describe and compare the distributions. Distributions of returns from research are notoriously skewed, so that a very small number of projects turn out to be responsible for much of the total payoff.

Of course, all this is familiar to venture capitalists, who consider even a 10 percent "hit rate" to be very satisfactory in betting on technology based companies. The pharmaceutical producers are also familiar with the fact that at any one point in time it will be only one of their products that generates most of their sales revenues. To take a rather different case illustrating how highly skewed are the appropriable direct payoffs from academic (so-called "basic") research, consider the following three facts about the distribution of returns to Stanford University from the licensing of its patents during the period 1970-1992: (1) only 400 patents, represently 17 percent of the total number of inventions disclosed to the University's Office of Technology Licensing, produced any financial returns; (2) among those 400, the 15 top revenue- earning patents were responsible for 80 percent of the aggregate cumulated revenues: (3) 46 percent of aggregate revenues resulted from one patent alone. ${ }^{22}$

So, when we think about the economic payoffs from $R \& D$, we should be considering what is implied for the size of the variance, and the degree of skew, as well as how they will average out. But, were we to examine the available record of past $R \& D$ investments in those dimensions, we would be mistaken to regard the results ascharacteristics of some

${ }^{22}$ See Nadine F. Skuble, "University Technology Licensing: A Case Study of Stanford's OTL," Stanford University Economics Department Undergraduate Honors Thesis, May 1994: pp. 29ff. The "big hit", of course, was the so-called Boyer-Cohen patent for "gene splicing", strictly descrbied as a "Process for the Construction of Biiologically Functional Molecular Chimeras." 
inherently stationary process; the distributions of returns are not an attribute of some "natural" features of the quest for scientific and technological knowledge. Rather, they reflect many of the specifics of the historical context in which those $R \& D$ expenditures were made, including the particular set of institutional and organizational arrangements through which the R\&D dollars were channelled and spent. There is no basis for supposing that the results could be replicated by spending the same sums under quite different institutional arrangements.

So now we have arrived at the nub of the issue -- what is the form of the knowledge products that emerge from research, and how does that affect what is done with them? What comes out of a given expenditure in the performance of $R \& D$ is not an economic benefit in the first instance. Rather the outputs can be conceptualized in terms of knowledge products, and a given project may generate a range of "results" are located in a space whose dimensions are the extent to which the information is public rather than private, tacit rather than codified, and fully disclosed rather than restricted. Where your research finding are positioned in this "knowledge product space" thus has a bearing on the modes and costs of others' access to the new knowledge, and also on how readily the economic benefits from utilitiarian applications of the cognitive advances can be appropriated by the research perfformers, or by the national political units in which they are situated.

In a 1994 study for the OECD, Dominique Foray and I introduced this conceptual framework, and made the point that there is a mapping from the organizational characteristics of the research environment to the distribution of outcomes in the scientific and technological knowledge space. ${ }^{23}$ Some of the considerations that give rise to that are quite direct, such as whether the $R \& D$ is performed in a teaching environment and so creates skilled personnel as a by-product of the use of research assistants. Other connections have to do with the incentives or codification, and the requirements that interests in intellectual property rights may impose. Because some organizations have a mixture of goals, e.g. the university research lab, or must accept constraints on their internal operating procedures as the price of being able to interface with other

${ }^{23}$ See OECD Document STI/CSTP/TIP 94(4), 25 April 1994, published in revised form as $P$. A. David and D. Foray, "Accessing and Expanding the Science and Technology Knowledge Base", STI Review--Science, Technology and Industry, No.16, Paris, 1995. 
organizations (allow eventual publication if you are a business that is cooperating with academic researchers) the positioning of products in the disclosure -secrecy space will not be the same in all kinds of organizations.

Research outputs, as information, are used for more research as well as being taken immediately into the realm of development for utilitarian applications. The distribution of knowledge products obviously affects the conditions and terms of access, and so affects the rate of generation of further innovations. Since some of those are likely to show up as affecting the returns on the orginal $R \& D$ performance, this is another channel through which the characteristic positioning of outputs in knowledge product space affects the distributions of private and social returns and the relationship between the two. When all property rights are secured it is likely that the middle and lower end of the distributions of private returns will be raised, but since the upper tail of returns is likely to be more sensistive to the synergetic combination of ideas and processes, tight intellectual property protection will be likely to inhbit exploration of such new combinations. So, whereas the private returns distribution might be raised enough to offset the suppression of some big hits, the higher private returns essentially redistribute the benefits towards the initial discoverers and away from would-be imitators and consumers. But, that does nothing to offset the reduction of the upper end of the distribution of social returns.

The phenomenon of institutionalization plays a key role here, because, otherwise, critics could could rightly say that there isn't any reason to believe the distribution of an organization's knowledge products in the knowledge-space would be constrained by the organization's characteristics. It is true that social policies and government requirements could mandate or at least create incentives for the production of certain mixes of knowledge products, and that the influence of such interventions could extend across the whole gamut of entities in which R\&D-like activities were performed. But, government policies themselves are framed for certain types of organizations, e.g., profit-making companies, non-profit foundations, universities, government laboratories, institutes, etc. Institutionalization has a role, in short, in creating typical organizational profiles, or categories, so that in considering the array of possible organizational arrangements it is found that not all the permunations and combinations are used; various rules and 
procedures will readily go together as packages. ${ }^{24}$ If you recruit from academic science circles and reward academic prestige, it is very difficult to forbid publication entirely -except in wartime or under similar conditions of national emergency. If you hire engineers for their access to networks of professional contacts external to your firm that will help solve your design problems, it is more than likely that you will wind up having to tolerate their trading in trade secrets -- as Eric von Hippel has found. ${ }^{25}$

What these considerations suggest is that the mix of organizational types in an economy will affect the location of the distribution of aggregated reseearch outputs in the knowledge product space. We would therefore do well to pause for a careful look at some of the problems that may emerge if we were enthusiastically to proceed with the wholesale implementation of the post-modernist vision of science. That is where serious attention to the potential impacts of new evaluation methods and performance indicators, as well as of restructurings and reforms of in research organizations is most called for.

Should there be persisting doubts concerning the need for care and caution when proceding in such matters, perhaps it will prove salutary for me to close my plea by referring to the conclusions that emerge from recent analyses of what went wrong with Soviet science and technology. The key problem with Soviet science was not that the regime failed to allocate enough resources to the performance of $R \& D$, nor even that they had the wrong priorities with regard to the fields of research in which to invest. Of course, mistakes of that sort were made, but it can be seen in retrospect that priorities sometimes were set erroneously by science and technology directors in the West -- in both the private and public sectors. The thing that stands out is the very high costs of the Soviet R\&D effort, some of which were reflected in the high ratio of RTD expenditures to GDP. Again, this ought not be read as an error in seeking to be too high-tech for an economy that still had a large and rather backward agricultural sector. Under the Soviet regime science

\footnotetext{
${ }^{24}$ The idea of complementarities in organizational design is spelled out in P. A. David, "Why are Institutions the 'Carriers of History'? Path-Dependence and the Evolution of Conventions, Organizations and Institutions", Structural Change and Economic Dynamics, 5((2), 1994: pp.205220; analytically it is related to the idea that certain bundles of strategies will appear more likely in the choices firms make regarding manufacturing methods, product line breadth, inventory management, etc. (see P. Milgrom and J. Roberts, "Modern Manufacturing," American Economic Review, 80(3), May, 1990.

25 See E. von Hippel, "Trading Trade Secrets," Technology Review, February/March 1988:pp.58-64.
} 
institutions were formed within the framework of the administrative command system, which gave rise to "top down" organizational forms and mechanisms of operation and management; moreover, the mode of organization also tended to foster the isolation of the various ministries, and of the production units and research institutes that were placed under their direction. In the words of a recent OECD report: ${ }^{26}$

"The structure imposed on scientific activities [in the USSR] thus did not promote, and indeed often hindered, the dissemination of scientific results. Research was duplicated, and the use of $R \& D$ results was restricted. When the science network ceased growing in the mid-1980s, dependence on parent departments continued, with the result that scientific organisations become even more isolated, and mobility of scienfic personnnel was low."

In short, Soviet scientific and technologically efforts became crushingly inefficient primarily as a result of failures in institutional structure and organizational design.

\section{A Summing $U p$}

By this point I am confident of having met my professional obligation as an economist to demonstrate the truth of the "No Free Lunch" theorem on every occasion possible, and, indeed, have gone beyond that, by proving a corollarly proposition, namely, "Free Dinners are even more costly than Free Lunches." I therefore turn immediately to the task of imparting summary messages. These I offer in the form of the following six "pillars of wisdom":

First, knowledge systems are complex and intricate social structures in which the details of institutional norms and organizational incentives really do matter.

Second, what you are doing, and what we are doing in this Symposium is consequential and important. The impact of $R \& D$ investments is not something that is just out there to be measured, it reflects the impact of $R \& D$ policy measures and management tools among which public, published indicators and evaluation procedures are very influential. They affect the workings of the organizations whose impact you are trying to measure.

${ }^{26}$ Committee for Scientific and Technological Policy/DSTI, "Science, Technology and Innovation Policies -- Federation of Russia: Background Report," OECD, Paris, 16 September, 1993: p.92. 
Third, it's a good idea to try to understand the particular functions of a class or research organizations that is performing well, and the possible connections that good performance in that dimension might have with the limitations and failings in other respects. It's especially good to understand that before one disrupts the organization in an attempt to improve its performance. Evaluations and indicators therefore ought to be designed and presented to provide multidimensional profiles of research institutions or particular research units, rather than describing single facets in isolation. Such units belong to complex systems performing a multiplicity of functions that are complementary.

Fourth, one should foster institutional innovation as the way to rebalance the mix of organizational types which have distinctive performance profiles. In science and technology knowledge systems there are important complementarities and synergies among the performance dimensions. Some research does need to be isolated from user-driven concerns, whereas other research needs to embedded in the matrix of anticipated applications.

Fifth, mid-course corrections in research program management are among the most valuable actions that evaluation exercises can produce, because paradigm-shifting research is what usually creates hitherto unimagined arenas of application, and existing applications contexts often are hostile environments in which to explore radically new ideas.

Sixth, remember the agreeably wise piece of advice enunciated yesterday by Tom Brzustowski, when he spoke about organizational innovation reform, and said: "Mix, do not blend". Resisting pressures to homogenize and standardize the differences in organizational structures and performance in different dimensions is vital to maintaing diversity and generating novelty at the cognitive level. Unfortunately, the opposite effects can be procured all too easily, intentionally or otherwise, through the imposition of standardized, uniformly applied methods and measures of assessment and evaluation.

At Oxford, my older colleagues tell me, the rooms in which I have my study were occupied by T. E. Lawrence ("Lawrence of Arabia") during his time as a fellow of All Souls College. I therefore searched very hard to find Seven Pillars of Wisdom for you take away as a souvenir of this event. But I have not been in those rooms a very long time, so for now you'll have to manage with just the six that I've brought with me tonight. I promise to keep an eye open for the one I've overlooked. 